\title{
Analysis of Open Space at Engineering Faculty of UMJ: Physically Possible and Legally Permitted
}

\author{
Yeptadian Sari ${ }^{1}$ \\ ${ }^{1}$ Architecture Department, Engineering Faculty, UMJ, Indonesia \\ yeptadian.sari@ftumj.ac.id
}

\begin{abstract}
Fakultas Teknik Universitas Muhammadiyah Jakarta has nine programs, including undergraduate programs in civil engineering, electrical engineering, chemical engineering, mechanical engineering, industrial engineering, architecture, informatics engineering, D3 OAB, and masters of chemical engineering. All programs are located in one building in the center of Jakarta that has strict land regulations. The fixed nature of the land, but the increasing number of requests or needs makes land one of the most promising investment areas. To improving efficiency on land limitations, it is necessary to optimize land use. But the fact is, there are still many lands that have not been used optimally for the landowner due to unfavorable reasons, likewise, for open space owned by UMJ, which is not appropriately utilized. This research's expected outcome is the best utilization of FT UMJ open space by taking into account the criteria physically possible, legally permitted, financially feasible, and have maximum productivity.
\end{abstract}

(c) 2018 IJBESR. All rights reserved.

Keywords: FT UMJ, Land Utilization, Open Space

\section{Introduction}

Jakarta Muhammadiyah University, or hereinafter referred to as UMJ, has several faculties, including the engineering faculty. The location of the Faculty of Engineering or also known as FT, is different from the locations of several other UMJ faculties. The location of FT $\mathrm{UMJ}$ is in the center of Jakarta.

FT UMJ itself has 9 (nine) study programs, which include undergraduate programs in civil engineering, electrical engineering, chemical engineering, mechanical engineering, industrial engineering, architecture, informatics engineering, $\mathrm{D} 3 \mathrm{OAB}$, and masters of chemical engineering. All study programs are located in one building in the center of Jakarta that has strict land regulations.
The land is a unique property and has a particular character, especially in its scarcity and usefulness. This is due to the limited amount of land or relatively fixed land supply. Still, the human need for area tends to increase to make the property have economic value, while physical characteristics and facilities influence land use. According to [1] physical characteristics that affect land values include size and shape, topography, utility, site development, location, and environment.

The influence of the land's location on its value is essential because each piece of land has its uniqueness based on its site. In determining the location for specific economic activities, location factors are the primary consideration. Therefore regulations are needed as a controlling tool and within the scope of the city implemented in the City Spatial Planning General Plan (RUTRK), which is then further 
elaborated in the City Spatial Detail Plan (RDTRK). The RUTRK is used as a guideline in space, and this plan also contains guidelines for land use.

The fixed nature of the land, but the increasing number of requests or needs makes land one of the most promising areas of investment. To improving efficiency on land limitations, it is necessary to optimize land use. But the fact is, there are still many lands that have not been used optimally for the landowner due to unfavorable reasons.

Many properties have been established on land, but some of the lands is abandoned or not appropriately utilized by the owner for various reasons. This happens because the property is built without using optimum land use and use analysis. It is appropriate that the property to be built on the land of an area can provide maximum and efficient benefits so that the region's results can be felt. Therefore, it is necessary to calculate the most possible and permitted uses of an empty or constructed land, which is physically possible, supported, or justified by regulations.

Things like those mentioned earlier also occur in FT UMJ open land. A location that is not too broad is used for 9 (nine) study programs and its place in the center of the city, making the open land in FT UMJ inadequate in size. Currently, the public property in FT UMJ is still abandoned, and its use is unclear. Sometimes it is used as a motorbike parking area, which sometimes scrambles with a car park, sometimes it is used as a sports ground by students, and sometimes it is recognized by some student associations as their property.

Then it is necessary to do a Highest and Best use (HBU) analysis on FT UMJ's open land to determine the highest and best use of the property by using criteria physically possible, legally permitted, financially feasible, and have maximum productivity.

\section{Material and Methods}

Direktorat Jenderal Kekayaan Negara states that the HBU analysis is a concept that is well known in the field of real property asset management, both in terms of asset optimization and asset valuation. HBU analysis is an analysis of the best and highest use of vacant land or land that is considered to be empty (land as vacant). This analysis covers four main points: physical feasibility analysis, legally permissible analysis, financially feasible analysis, and maximally productive analysis. A property is said to have fulfilled the HBU criteria when it is physically possible, legally permissible, economically viable, and can provide the maximum results [2].

Highest and Best Use means maximum use of land that is physically possible and most likely to be used, legally permitted, and financially feasible. In conclusion, it produces maximum use from the property.

Maximum usability is the use that is legally permitted and has a high enough possibility to be used for an empty land or a plot of land that has already been built. It can be carried out physically and has sufficient financially feasible support and produces maximum usability.

Site (Site) can be defined as land that has been developed and is ready to be used for specific land use purposes. A site can have two developments, namely onsite and offsite improvement, to make the land ready. The development of this site includes, among others: the provision of drainage systems, dirty water channels, utility lines (electricity, telephone, water, and gas), mapping, and the making of entrances/exits to main roads. Land or site description is a list of factual data that includes a description of ownership (legal description, another title, and record data) and information related to physical characteristics. Land/site analysis is a careful study of factual 
data pertaining to environmental characteristics that create, enhance or reduce the use and marketability of the land/site as the land/comparison site [1].

The building is a physical form of construction work integrated with the place of domicile, partly or wholly on top and inland and water, which functions as a place for humans to carry out their activities, both for residential or residential, religious activities, business activities social, cultural and special activities (Minister of Public Works Regulation number 29 / PRT / M / 2006).

Assets are goods or objects consisting of immovable objects and movable objects, both tangible and intangible, which are included in company assets/assets. The existence of assets is beneficial for the company in carrying out its activities. However, if the asset is not properly maintained and managed, it will be able to hamper its activities. Then there needs to be asset management that can handle all assets owned [3].

Market forces also shape market prices. Data collected and analyzed to calculate the benefits of land are also used to provide opinions by property business operators on Highest and Best Use at a time. The Highest and Best Use properties analyzed to provide a basis for competitiveness analysis in the market, so Highest and Best Use also reflects the market value of a land.

According to Novasari et al. [3], HBU Factors for Property in the Form of Land and Buildings:

1. Physical, including:

- Land shape and soil size

- Land topography

- Land location / Land location

- Facilities and infrastructure

2. Government Regulations, including:

- Allocation is based on City Planning

- KDB (Basic Building Coefficient)

- KLB (Building Floor Coefficient)
- KDH (Green Basic Coefficient)

- GSB (Building Borders)

- Maximum Building Height

3. From the development alternatives following government regulations, the option with the highest yield is chosen.

Referring to previous research, trying to find the common thread, several previous studies, including [4], analyzed vacant land in Jemur Gayungan II Surabaya. As an alternative commercial property that is used in the form of apartments, hotels, and offices. The conclusion from this study found that alternative hotels as the best land use with the highest land value are IDR 9,772,718 / $\mathrm{m} 2$, with a productivity increase of $486 \%$.

Akmaluddin and Utomo took a case study on land on J1. Gubeng Raya No.54 Surabaya covering an area of $1,150 \mathrm{~m} 2$ planned to be built by the hotel. The study results obtained alternative hotel commercial property with the highest and best use of land use with a land value of $\operatorname{Rp~67,069,980.31~/~m2~[5].~}$

Priambudi and Haryanto also examined the Highest and Best Use in Semarang City. The development of the property business in the city of Semarang has started to increase significantly since 2010 . This is marked by the rise of high rise buildings such as malls, office complexes, and hotels. On the other hand, the availability of land in the city is increasingly limited; thus, it is necessary to optimize land use. One way is to establish a property business with a view of maximizing land management to achieve high selling values [6].

The purpose of the research conducted by [6] is to examine the most optimal land use using the Highest and Best Use (HBU) method and solicit public opinion regarding its development plans. The method used in the study was mixedmethod (quantitative and qualitative) with the location of the research being the Raden Saleh 
Cultural Park (TBRS) and Wonderia with an area of $90,000 \mathrm{~m} 2$ or $9 \mathrm{Ha}$.

The location is an area that has been selected by Trans Retail Property, which is most likely for the Trans Studio Semarang development plan. The choice of location is based on the strategic location of the land, but the tourist attractions on the vehicle are less attractive. So that land use in these locations is less than optimal. Based on the results of the analysis, it can be concluded that in terms of the investment approach, the Raden Saleh and Wonderia Cultural Park Complex is feasible and allows it to be developed into a hotel and mall that can generate high profits.

In addition to being able to produce an economical, social benefit for the surrounding environment, a re-design of existing urban forest utilization is needed without losing its function, to create a balance between private, public, and the best and highest use of land in the TBRS and Wonderia complexes.

From the three previous research studies, a common thread was found, namely research in the Highest and Best Use, to determine the highest and best use of land or building. Some of them even make a profit or profit from land use as the primary benchmark. However, this only applies to commercial properties, unlike the case with the open field of the Faculty of Engineering UMJ. However, it does not rule out that the results of this study will add to the profit or profit of FT UMJ itself.

\section{Results and Discussions}

This research is based on an analysis of the Highest and Best Use (HBU) of the open land of the Faculty of Engineering UMJ based on a physically possible study and a legally possible study attached to the property.

There are two data sources and data collection methods, namely:
1) Primary Data, i.e., research data obtained by myself through direct observation on FT UMJ open land objects.

2) Secondary Data, i.e., research data which is obtained by itself through various reliable sources.

Observations by measuring objects that are open land in the Faculty of Engineering, Muhammadiyah University, Jakarta. Besides recording the results can be done with the help of an electronic recording device in the form of a camera. From the observation, it was found that there are three open spaces in the FT UMJ area. They are shown at the Figure 1. Three Areas of FT UMJ Open Spaces

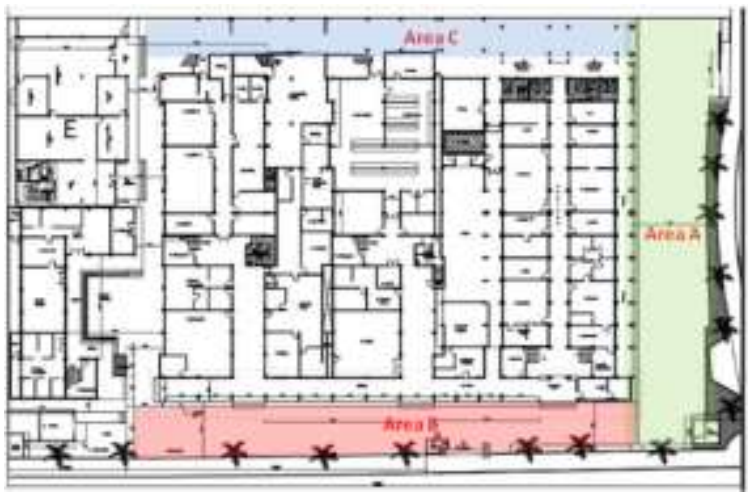

Figure 1. Three Areas of FT UMJ Open Spaces

Figure 1 shows that FT UMJ has three outdoor space areas; the first is Area $A$, which is $9.9 \mathrm{mx} 59 \mathrm{~m}$, Area B is $6.9 \mathrm{mx} 83 \mathrm{~m}$, and the last is Area C, which has an area of $4.5 \mathrm{mx} 83 \mathrm{~m}$.

Based on direct observation, the outer space requirements at FT UMJ are as follow:

1. Motorcycle parking area

2. Car parking area

3. Student communal area

4. Green area

The criteria for physically enabling include land shape and land size, land topography, land location/land layout and finally, the facilities and infrastructure or accessibility, the 
explanation of which will be explained as follows:

Land Shape and Size. The shape of the land is square, with a total land size of $5,841 \mathrm{~m} 2$, with the remaining open area around $1,530 \mathrm{~m} 2$ so that the remaining open space is only about $38 \%$ of the whole land. The shape of the rectangular open land, elongated rectangle. Many shortcomings with this form of open land, will be challenging to use for communal space, one of the functions of open space needed by students of FT UMJ.

The topography of the land in the Cempaka Putih area is quite flat, especially in the Faculty of Engineering of UMJ, which tends to fall a few centimeters from the ground surface outside the campus area. It means that the FT UMJ campus area is very likely to experience flooding; the dense activity around the campus also affects the land surface fall.

FT UMJ is located in an area that has the predicate "P" or it can also be called "Padat," which is mean "Crowded." This means that this area is an area full of activities, and the location of FT UMJ is also an area designated as a public and social service zone and office, trade, and services zone. This means that FT UMJ does not break the rules of land use.

Facilities, infrastructure, and accessibility available in the FT UMJ area are only for certain people; not everyone can come to this area. Stakeholders in this building can only access this area. The horizontal and vertical access facilities are available only for ordinary people who do not have disabilities (because the design of the FT UMJ campus's accessibility is not universal at all.

Legally Permissible Criteria. Based on DKI Jakarta Provincial Regulation no. 1 of 2014 Regarding detailed spatial planning and zoning regulations, zoning discussed here is the land zone used by FT UMJ. It includes the public and social service zone as well as office, trade, and service zones so that it can be seen that FT UMJ does not violate the designation land. Then it can be legally determined by GSB (Building Border Line), KDB (Building Base Coefficient), KLB (Building Area Coefficient), $\mathrm{KDH}$ (Green Base Coefficient), and KB (Building Height). After a literature study and observation, it was found that the measurements were explained in numbers as below:

GSB $4 \mathrm{~m}$ means the building border is 4 meters from the roadside, and the building border should not be given a structure / may not be built. KDB 55\%, means that the necessary building coefficient allowed is only $55 \%$, the building base attached to the FT UMJ land is actually only $55 \%$. KLB 3, means that the ratio of building area that can be built is three times the area of land. KDH $30 \%$, says the necessary green coefficient must be made at least $30 \%$ of the land area. KB 8 floors in question mean that the maximum height of the building is eight floors.

Area A has an area of $584 \mathrm{~m} 2$ and is the widest open area, so far used as a two-wheeled vehicle parking area, but there are times when some of this area is used as a student communal area. GSB does not affect the existing land area, because 5 meters from the edge of the road section have been utilized as pedestrian or pedestrian path. Therefore, there is no reduction in land size for this area.

Its size tends to be large and the most extensive among all Open Areas in FT UMJ, making it most likely to be used as a parking area for twowheeled and four-wheeled vehicles. During this time, if you see the existing, four-wheeled vehicle parking, it is always in violation of local government regulations that should not be on the side of the road; therefore, the four-wheeled vehicle parking area was planned in. Open Area A. 
For the time being, the design plan for parking spaces for two-wheeled vehicles and fourwheeled vehicles is shown in Figure2. Design Area A for Parking Area.

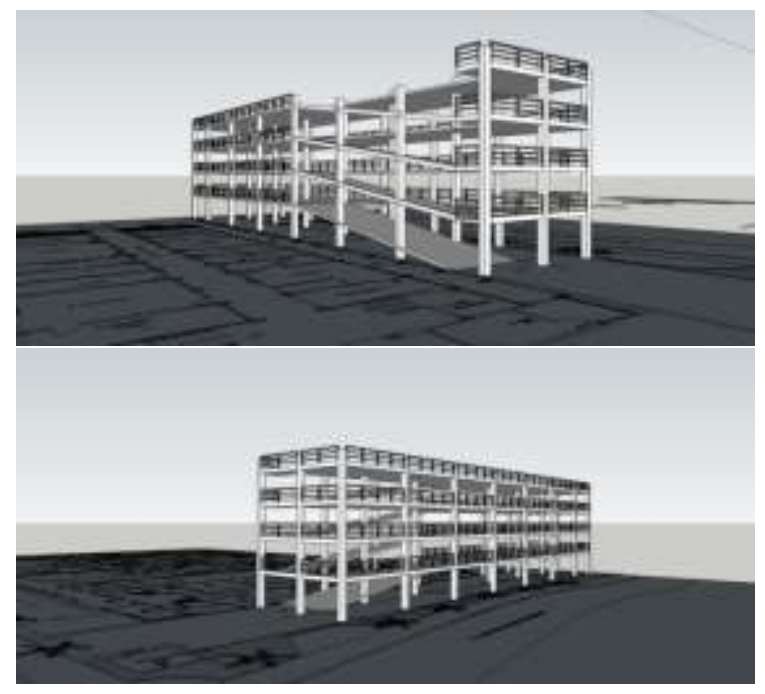

Figure 2. Design Area A for Parking Area

\section{Conclusion}

FT UMJ has three open spaces, one of which is most able to meet the needs of open space in the area, namely Area A. Area A can be used as a multilevel parking area and student communal area. The criteria for physically possible include land shape and land size, land topography, land location/land layout, and finally, the facilities and infrastructure or accessibility. An open area that physically possible to meet the needs of open space at UMJ is Area A.

Legally permissible criteria. Based on DKI Jakarta Provincial Regulation no. 1 of 2014 Regarding detailed spatial planning and zoning regulations, zoning discussed here is the land zone used by FT UMJ. It includes the public and social service zone as well as office, trade, and service zones so that it can be seen that FT UMJ does not violate the designation land. Then it can be legally determined by GSB (Building Border Line) 5 meters, KDB (Building Base Coefficient) 55\%, KLB (Building Area Coefficient) 3, KDH (Green
Base Coefficient) 30\%, and KB (Building Height) 8 floors.

All legally permissible criteria owned by FT UMJ say that FT UMJ can still cultivate the open space so that it can be utilized optimally. This research can be the first research of Fakultas Teknik UMJ's open space highest and best use. For the next study, the researcher would like to find any possible design to make the open space more compatible than before.

\section{Acknowledgement}

This scientific article was based on the research of PAKARTI FT UMJ, funded in 2019, entitled Analysis of the Highest and Best Use of Open Land in the Faculty of Engineering, University of Muhammadiyah Jakarta

\section{References}

[1] Hidayati, W. dan Harjanto, B., 2013, Konsep Dasar Penilaian Properti, BPFE, Fakultas Ekonomi dan Bisnis UGM, Yogyakarta

[2] Direktorat Jenderal Kekayaan Negara (2010), Pemahaman Sederhana Konsep Higest and Best Use Analysis,

https://www.djkn.kemenkeu.go.id/artikel/baca/2305/Pe mahaman-Sederhana-Konsep-Highest-And-Best-UsesAnalysis.html, diakses tanggal 2 Nopember 2018 jam 06.24 WIB

[3] Novasari, A., dkk. 2014, Analisis Highest And Best Use (HBU) Gama Book Plaza. Digital Library UGM.

[4] Faradiany, F.V. dan Utomo, C. 2014. Analisa Highest and Best Use Pada Lahan Kosong Di Jemur Gayungan II Surabaya. Surabaya : Jurnal Teknik ITS 3 (2), C61-63

[5] Akmaluddin, A and Utomo, C. 2013. Analisis Highest and Best Use (HBU) pada Lahan Jl. Gubeng Raya No.54 Surabaya. Surabaya: Jurnal Teknik ITS 2 (1), C6C10

[6] Priambudi, B. N. dan Haryanto, N. 2015. Optimalisasi Lahan Untuk Pengembangan Rekreasi Dan Budaya Dengan Metode Highest And Best Use (Hbu). Jurnal Pengembangan Wilayah dan Kota UNDIP. Volume 11 (4): 403-412 Desember 2015, hal 403-412. 